\title{
Fact or fiction?
}

\section{Library leadership of a campus-wide intellectual theme}

E very year Illinois Wesleyan University organizes a campus-wide intellectual theme. In 2019, the Ames Library at Illinois Wesleyan proposed the topic of fact or fiction for the annual intellectual theme. This program is noteworthy to the profession because the intellectual themes are truly campus-wide, engaging students at all levels and integrating curricular and co-curricular components. These intellectual themes go beyond the more common shared first-year experiences or One Book, One School programs. This article is a brief case study of the library-led Fact or Fiction intellectual theme.

\section{Introduction}

In 2016, the Oxford Dictionaries selected post-truth as their word of the year, and the White House coined the term alternative facts. Enabled by social media platforms, the rapid spread of fake news has deepened political polarization and undermined basic democratic processes. As librarians know all too well, learning to discern fact from fiction goes far beyond simply evaluating news and social media posts. Fundamentally, it is a matter of becoming an information literate critical thinker. Given this context, 2018 was the right time for the Ames Library at Illinois Wesleyan University to propose the topic of fact or fiction for the 2019-20 campuswide intellectual theme.

For many years, Illinois Wesleyan, a private, residential liberal arts school with
1,600 students located in Central Illinois, has organized an annual intellectual theme to enhance both student learning and the liberal arts experience. Themes are truly campus-wide, engaging students at all levels and integrating curricular and cocurricular components. These intellectual themes go beyond the more common shared first-year experiences or One Book, One School programs and strive to be both relevant and interdisciplinary. Past themes have included Changing Climates, Evolution of Revolution, Women's Power, Women's Justice, Nation(s) Divided?, and Walls and Bridges. Any faculty member, or group of faculty, can propose a theme. Fact or Fiction was the first theme proposed by library faculty. The proposal was selected by the Intellectual Theme Committee for the campus-wide program during the fall 2018 semester.

\section{Program description}

For the curricular component of the intellectual themes, faculty members have the option to include one or more of their classes each semester in an intellectual theme course cluster. Content of the classes included in the course cluster must engage with the theme in a sub-

Christopher Sweet is information literacy librarian at Illinois Wesleyan University's Ames Library, email: csweet@iwu.edu

(c) 2020 Christopher Sweet 
stantial way. In some classes, the subject matter of the theme is incorporated into the entire class, while in other classes the theme may be the focus of a major assignment. Given the subject matter of the theme, library faculty were asked to provide information literacy instruction sessions for many more of these courses compared to our average instruction numbers across the curriculum. Whether library-led or not, it is clear that actively engaging with the annual theme advances the library's mission and strategic goals.

Students enrolled in one of the course cluster classes are also required to attend two major course cluster events each semester: a kick-off at the beginning of the semester and an open house near the end of the semester. The kick-off sessions are led by the theme coordinator and are intended to be interactive lunches that both orient students to the theme and get them excited about being part of an intellectual theme class. The library-led kickoff featured an activity in which tables of students needed to reach a consensus on whether a displayed statement was either fact or fiction. As a way of highlighting the interdisciplinarity of the cluster, these statements were solicited ahead of time from all the faculty participating in the course cluster. This activity was followed by a Kahoot quiz, in which tables of students competed at identifying logical fallacies. The questions and handouts for this quiz were adapted from the School of Thought's website. ${ }^{1}$ The kick-off closed with a keynote speech from the author entitled: "On Bullshit, Skepticism, and Belief." ${ }^{2}$ Nearly a quarter of the school's student body participated in this kick-off event.

The semester-end open houses have taken place in the library for many years and are a great way to highlight undergraduate research that takes place within the course cluster. During the open house, students present research in a variety of formats. Poster presentations are the most common format, but there have also been PowerPoint presentations, dramatic readings of creative writing, and even interactive, student-led yoga sessions. The library provides some in-class instruction regarding poster formatting and also prints the majority of the posters in-house. The open houses are routinely attended by the president, provost, and dean of students and they have been covered by local media. ${ }^{3}$ For the Fact or Fiction open house, more than 100 students from 15 different courses presented original research. From the library perspective, the open houses usually yield the highest daily gate count of the year for our library. The fall 2019 open house saw 1,275 people enter the library. Contrast this number with last year's daily average of 498. Beyond the gate counts, the open houses are a way to showcase students' undergraduate research, which the Association of American Colleges \& Universities (AAC\&U) has designated a high-impact undergraduate practice. ${ }^{4}$

Another element of each intellectual theme is a required summer reading selection for all incoming students. The reading is tied to the intellectual theme, and I have been featured as a speaker later in the semester for the past few years. For the Fact or Fiction intellectual theme, the library, along with the summer reading committee, selected Tara Westover's Educated. ${ }^{5}$ This book was selected because it has engaging material and spoke directly to the value of education for overcoming misinformation. Incoming students read the book over the summer and then participated in small group discussion sessions led by faculty and staff. Library faculty routinely serve as facilitators for these small group discussions. Obviously, this type of summer reading program for incoming students is fairly common among small and midsize schools. Where Illinois Wesleyan's program differs is in its close connection to the intellectual theme that persists throughout the school year. Since incoming students are required to read the book over the summer, they are introduced to the intellectual theme before 
their first day on campus. The library traditionally develops a webpage related to the summer reading selection that contains author biographical information, articles and videos related to the reading, and discussion questions.

Each theme also includes a variety of co-curricular events open to all students. Highlights of the co-curricular events include theme-related speakers at three major campus events: President's Convocation (fall), Founder's Day Convocation (early spring), and the John Wesley Powell Student Research Conference (late spring). The practice of tying major speakers to the theme uses existing budget lines and helps create continuity throughout the year. Beyond these major speakers, there are always additional theme-related speakers sponsored by departments and student groups, discussion panels, and film screenings. Illinois Wesleyan's Center for Human Rights and Social Justice is another important partner in co-curricular programming. Every fall the center hosts an evening Human Rights Workshop followed by a spring weekend-long Human Rights Undergraduate Research Conference. This fall, the workshop was "Fact or Fiction," and the spring conference was "Constructing Truths in Human Rights."

\section{Planning}

The success of Illinois Wesleyan's annual intellectual themes is based, in part, on buy-in and active participation from a wide variety of campus units. The Intellectual Theme Committee solicits and vets proposals for future intellectual themes and helps coordinate the current theme. The intellectual theme committee includes members from the President's office, the Dean of Student, the Speakers Bureau, Office of Residential Life, Office of Diversity and Inclusion, Campus Chaplain, academic advising, marketing, teaching faculty, and library faculty. Unfortunately, the intellectual theme does not have a budget of its own, so its suc- cess is contingent upon financial support from the various campus units that make up the Intellectual Theme Committee.

Students are also directly involved in planning and implementing the annual intellectual themes. This process starts during the spring semester for that coming fall's theme. A group of students in a 300-level Marketing in Services Industries and Not-for-Profit Organizations class are assigned to create a full marketing plan for the annual theme. This marketing plan always includes logo designs, situational analysis, recommendations, and deliverables. The marketing plan for the Fact or Fiction theme included "customer" research in the form of student and faculty surveys about the theme. As part of the survey design process, students received feedback from the dean of students and the librarian coordinating the theme. The students then administered the surveys, analyzed results, and compiled a summary including recommendations.

After the marketing plan is complete, one student (ideally from the marketing class) is hired to work in the Dean of Students office as an intellectual theme intern. This intern's primary responsibility is implementation of the marketing plan, including additional graphic design work and managing social media accounts. In some instances, putting students in charge of a semi-official university social media account proved to be challenging. While the students were adept at creating content, the content fell short of university marketing standards. Written social media guidelines and a good deal of faculty oversight helped to address these issues.

\section{Conclusion}

Due in part to the timeliness of the topic, and its highly interdisciplinary nature, the Fact or Fiction intellectual theme had better participation than any previous themes at Illinois Wesleyan. Twenty-sev-

(continues on page 558) 
3. Ibid.

4. Ibid.

5. Rachel Scott, "Accommodating Faculty Requests and Staying True to Your Pedagogical Ideals in the 1-shot Information Literacy Session," Communications in Information Literacy 10, no. 2 (2016): https://doi.org/10.15760/comminfolit. 2016.10.2.29.

6. Association of American Colleges \& Universities, "Employers More Interested in Critical Thinking and Problem Solving Than College Major" [press release], April 10, 2013, https://www.aacu.org/press /press-releases/employers-more-interested -critical-thinking-and-problem-solving -college-major.

7. ACRL, "Framework for Information Literacy for Higher Education,” 2015, www.ala.org/acrl/standards/ilframework; Battelle for Kids, "Frameworks \& Resources," 2019, www.battelleforkids.org /networks/p21/frameworks-resources.

8. Ron Richart, Mark Church, and Karin Morrison, Making Thinking Visible: How to Promote Engagement, Understanding, and Independence for All Learners (San Francisco, California: Jossey-Bass, 2011).

("Fact or fiction?," continued from page 552)

en courses participated in the fall course cluster, reaching nearly 400 students, or a quarter of our student body. Student feedback regarding the theme has been positive. In particular, they liked the fastpaced and highly interactive kick-off event. The provost also reported hearing good feedback from students about this event. Unfortunately, the COVID-19 pandemic necessitated sending our students home after spring break and transitioning to online instruction. During the remainder of the spring semester, Fact or Fiction courses were taught online, but organizing any additional theme events, including a virtual spring open house, proved untenable.

From a library faculty member perspective, coordinating this intellectual theme was a rare opportunity to make a significant contribution to the university's curriculum beyond standard instruction sessions and reference support. In this context, coordinating the theme was certainly rewarding work, but given shrinking library faculty numbers, leading another theme anytime soon is unlikely.

The Intellectual Theme Committee is considering transitioning to team-based theme leadership that would reduce the overall workload and lower the barrier to future participation. Whether or not a given theme is led by the library, we have found it beneficial to continue supporting this unique curricular effort. ${ }^{6}$

\section{Notes}

1. School of Thought's website at https:// yourlogicalfallacyis.com.

2. Christopher Sweet, "On Bullshit, Skepticism, and Belief," (Keynote Speech, Fact or Fiction Kick-Off, Illinois Wesleyan University, Bloomington, Illinois, September 11, 2020), https:// works.bepress.com/christopher_sweet/47 / (accessed April 10, 2020).

3. Lenore Sobota, "Fact or Fiction? Illinois Wesleyan Students Study the Difference," Pantagraph (Bloomington, Illinois), December 4, 2019, https://www.pantagraph.com /news/local/education/fact-or-fiction-illinois -wesleyan-students-study-the-difference /article_58e0e1af-2a6a-5ee6-b0ba -4f91ff1dca4a.html (accessed April 10, 2020).

4. AAC\&U. "High Impact Educational Practices," https://www.aacu.org/leap/hips (accessed April 10, 2020).

5. Tara Westover, Educated: A Memoir (New York, Random House, 2018).

6. Further details about Illinois Wesleyan's Annual Intellectual Themes can be found at https://www.iwu.edu/annual-theme/. $\boldsymbol{n}$ 